\title{
マングローブ気根のガス交換機能に関する研究 $(\mathbf{1})$
}

\author{
矢吹万寿・北宅善昭・杉 二 郎* \\ 大阪府立大学農学部 $\cdot{ }^{*}$ 東京農業大学総合研究所
}

Studies on the Function of Mangrove Pneumatophores (1)

\author{
Kazutoshi Yabuki, Yoshiaki Kitaya and Jiro Sugi* \\ College of Agriculture, University of Osaka Prefecture, Sakai 591, Japan \\ * Nodai Research Institute, Tokyo University of Agriculture, Setagaya-ku, Tokyo 156, Japan
}

\begin{abstract}
The function of the elected pneumatophores of two mangrove species, Avicennia marina and Sonneratia alba, was investigated. Experiments were carried out with detached samples from the habitat in order to clarify that the photosynthetic reaction takes place at the surface of the pneumatophore and plays an important role in the gas exchange between the pneumatophore and the root in the subsoil.

As a result, the gross photosynthetic rates of the pneumatophores of A. marina and S. alba were 3 and $11 \mathrm{mgCO}_{2} / \mathrm{dm}^{2} / \mathrm{hr}$, respectively, at the light intensity of $0.45 \mathrm{cal} / \mathrm{cm}^{2} / \mathrm{min}$. Their light compensating points were at $0.02-0.03 \mathrm{cal} / \mathrm{cm}^{2} / \mathrm{min}$ and similar to that of a shaded leaf. The diffusion rates of $\mathrm{O}_{2}$ from the pneumatophores to the roots in the light condition were higher than those in the dark condition. In addition, $\mathrm{O}_{2}$ diffusion rates increased when the pneumatophores were supplied with $\mathrm{CO}_{2}$ through their cut surfaces.

These facts show that $\mathrm{O}_{2}$ is produced by the photosynthetic reaction in the pneumatophores during daytime. Then $\mathrm{O}_{2}$ diffuses to the root in the subsoil where it is used for the root respiration. In addition, the respiratory induced $\mathrm{CO}_{2}$ diffuses to the pneumatophore and is used for the photosynthesis in the pneumatophore.
\end{abstract}

(Received February 23, 1990)

1990 年 2 月 23 日受付

\section{緒}

マングローブの多くの種は，気根をもっている．気根 の機能に関する研究は, Goebel ${ }^{1)}$, Karsten $^{2)}$ らに始まり, 最近では Scholander らの論文 ${ }^{3)}$ が代表的である. それ らによると, 気根は泥土中の根に $\mathrm{O}_{2}$ を供給する器官で あり, 気根表面の皮目と内部の通気組織を通じて, 根の 内部と大気中とのガス分圧の差により，ガス交換が行わ れるとしている. Scholander $ら^{3)}$ にると, 気根が水没 すると皮目が塞がれるため, 根内の $\mathrm{O}_{2}$ 濃度は $5 \sim 10 \%$ となるが，干潮になると 10〜 $18 \%$ まで回復する．これ は皮目 (lenticel) と気道 (aerenchyma passage)を通じて, 外界との空気の交換が行われていることを示し，気根が 水中から出たときの急激な空気の交換を助けている. こ
のようなガス交換と潮の干満との関係は, 昼夜の別なく 同様である.また気根の皮目をグリースで封じて空気の 交換を妨げると, 根内の空気の $\mathrm{O}_{2}$ 含有率は急速に低下

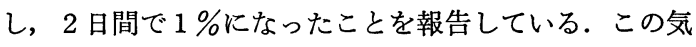
根の機能に関する実験が明快なため, 彼らの説明が今日 まで信じられてきた。

一方, 著者らは, タイ国ラノーン (Ranong) でマング ローブ林調査を行った際に, Avicennia 属やSonneratia 属の直立気根の表皮の下に葉緑素を含む層があることを 見いだした. このことは気根が光合成反応を行い， $\mathrm{CO}_{2}$ を固定し $\mathrm{O}_{2}$ を生成していることを意味するものである. よって日中には, 気根の光合成反応によって生じた $\mathrm{O}_{2}$ が通気組織を通って泥土中の根に拡散し, 根の呼吸に利 用されることが考えられる。

本研究ではこのような気根の機能に関する仮説を実証 
するために，まず直立気根が光合成反応を行っているこ とを確かめた，次に，光合成反応により生成した $\mathrm{O}_{2}$ が 根に拡散し，根の呼吸に利用され，またその呼吸により 生成した $\mathrm{CO}_{2}$ が気根に拡散し, 光合成反応に再利用さ れることも考古れるので, これについても確かめ, 根 と気根との間に $\mathrm{O}_{2}$ と $\mathrm{CO}_{2}$ の循環系が成立していること を明らかにした。

\section{材料および方法}

\section{1. 気根の光合成}

Avicennia marina および Sonneratia alba の直立気 根について光一光合成曲線を求めるため, 供試材料を沖 縄県西表島で採取し大阪府立大学農学部（大阪府堺市） の研究室に持ち㷌り, 採取 5 日後に光合成を測定した. 光合成速度は, 人工気象室内で開放型同化箱法により測 定した. 測定システムの概要を Fig. 1 に示す. 同化箱 は透明アクリル樹脂でできており, 同化箱流入空気およ び流出空気中の $\mathrm{CO}_{2}$ 濃度差から光合成速度を算定した. $\mathrm{CO}_{2}$ 濃度差の測定には, 差型赤外線 $\mathrm{CO}_{2}$ 分析計 (ZFP5 , 富士電機）を用いた. 気根は同化箱内に寝かせて並 ベ,上方から光を照射した. 光源には陽光ランプ(DR400/ TL)を用いた. 同化箱内温度は試料採取時の気温とほぼ 同様， $30^{\circ} \mathrm{C}$ に制御した.

\section{2. 気根から根への $\mathrm{O}_{2}$ の拡散}

気根の光合成により生成した $\mathrm{O}_{2}$ が根に拡散すること を確かめるため, 気根から根部に向から $\mathrm{O}_{2}$ の拡散を調 査した。

上述と同椂，西表島で採集した直立気根を用いて，制 御環境下で測定を行った. Fig. 2 に示すように気根の下 部切口にガラス容器 (容量 $300 \mathrm{ml}$ ) を取り付け, 容器内 部を $100 \% \mathrm{~N}_{2}$ ガスで充たした. その後, 容器内の $\mathrm{O}_{2}$ 濃 度の時間変化を光照射下 (光強度 $0.33 \mathrm{cal} / \mathrm{cm}^{2} / \mathrm{min}$ ) 抌よ び暗黒下で測定した.

次に，根の呼吸により生成した $\mathrm{CO}_{2}$ が，気根に拡散 し, 光合成に使われると考えられるので, 気根下部の $\mathrm{CO}_{2}$ 濃度を高めるために, 下部容器に $\mathrm{CO}_{2}$ 濃度 $8 \%$, $\mathrm{N}_{2}$ 濃度 $92 \%$ の混合ガスを充填し, 下部容器内の $\mathrm{O}_{2}$ 濃 度の変化を調べた. 容器内空気の $\mathrm{O}_{2}$ 濃度はガスクロマ トグラフ（モデル 663, 日立製作所製）を用いて分析し た. 試料空気の採取にはマイクロシリンジを用い, 試料 量は $0.2 \mathrm{ml}$ とした.

なお，実験中は気根上部にも同様なガラス容器を取り 付け, 急激な乾燥を防止した. また下部容器は光照射に よる温度上昇を防ぐため, アルミフォイルで覆い遮光し た.

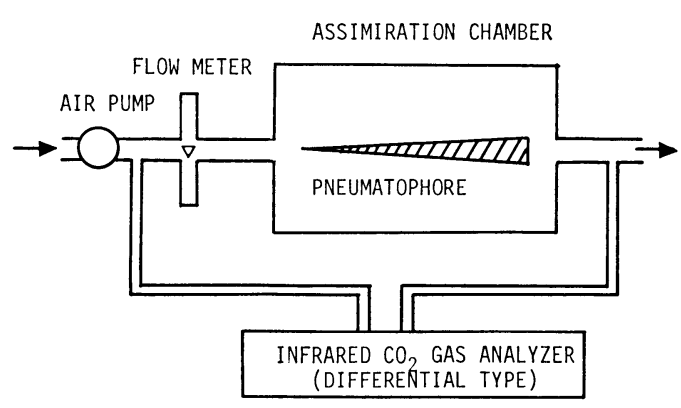

Fig. 1 Apparatus for measuring the photosynthetic rate of a pneumatophore.

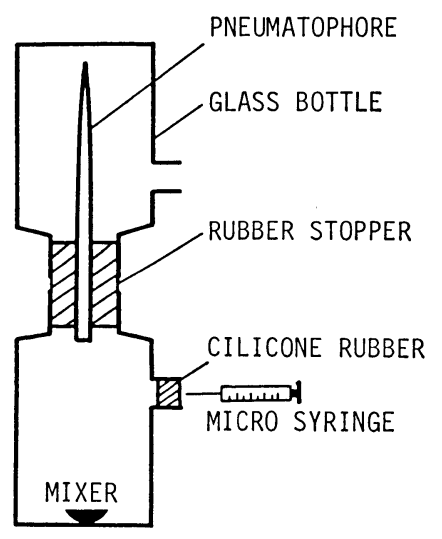

Fig. 2 Equipment for measuring the $\mathrm{O}_{2}$ exchange rate of a pneumatophore.

\section{結果}

\section{1. 気根の光合成}

Fig. 3 に気根の光合成速度と光強度との関係を示す. Avicennia marina では 12 個, Sonneratia alba では 3 個の供試体をそれぞれ同時に測定し，その平均值を図に 示した. それぞれの気根は地際で切除したものであり, Avicennia marina の気根の長さの平均は $11.1 \mathrm{~cm}$, 切 口の直径は $0.6 \mathrm{~cm}$, また Sonneratia alba の気根の長 さの平均は $8.7 \mathrm{~cm}$, 切口の直径は $1.1 \mathrm{~cm}$ であった. ま た図には参考として, Rhizophora stylosa の支柱根の光 合成速度, 呼吸速度も示した。

図の横軸に示した光強度は水平面での值であるので, 円錐形に近い気根の光合成速度を算出する場合, 単位面 積の取扱いが問題となる. ここでは光線方向に対して直 角な受光面積と考えられる気根の投影面積, すなわち光 線方向に直角となる気根の断面積で $\mathrm{CO}_{2}$ 吸収速度を除 した.なお呼吸速度については, 暗黒下での測定值であ るので, 試料の $\mathrm{CO}_{2}$ 放出速度をその全表面積で除して 


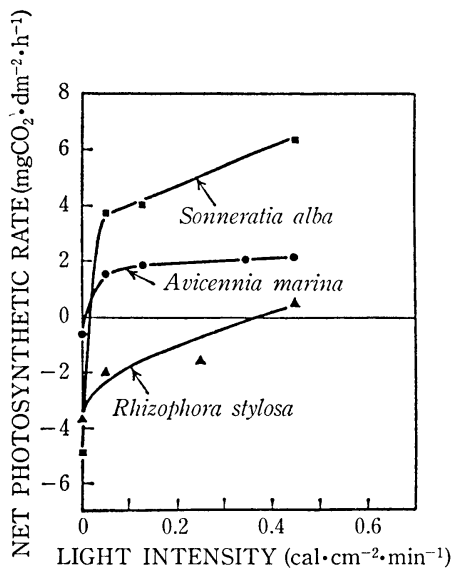

Fig. 3 Net photosynthetic rate of pneumatophores.

求めた.

光強度 $0.45 \mathrm{cal} / \mathrm{cm}^{2} / \mathrm{min}$ の時の Sonneratia alba 抒よ び Avicennia marina 気根の正味光合成速度はそれぞれ $6.4 \mathrm{mgCO}_{2} / \mathrm{dm}^{2} / \mathrm{hr}$ および $2.1 \mathrm{mgCO}_{2} / \mathrm{dm}^{2} / \mathrm{hr}$, 総光合 成速度はそれぞれ $11.3 \mathrm{mgCO}_{2} / \mathrm{dm}^{2} / \mathrm{hr}$ 抌よび $2.8 \mathrm{mg}$ $\mathrm{CO}_{2} / \mathrm{dm}^{2} / \mathrm{hr}$ であり, 明らかに気根が光合成反応を行っ ていることが実証された。両種の気根の光補償点は $0.02 \sim 0.03 \mathrm{cal} / \mathrm{cm}^{2} / \mathrm{min}$ とかなり低く, 陰葉的な特性を もっていた. また Rhizophora stylosa の支柱根も光合 成を行っていたが，その速度は前 2 種に比べて小さかっ た.

\section{2. 気根から根への $\mathrm{O}_{2}$ の拡散}

Avicennia marina の気根の切口を $100 \% \mathrm{~N}_{2}$ ガスの 入った下部容器 (Fig. 2) に入れ，上部に光を照射した場 合または暗黒下に置いた場合の, 下部容器内の $\mathrm{O}_{2}$ 濃度 の変化を Fig. 4 に示す. Avicenna marina の気根表面 には皮目があるため, 暗黒でも気根を通って $\mathrm{O}_{2}$ が大気 中から容器内に拡散してくるが, 明期には暗期の約 2 倍 の $\mathrm{O}_{2}$ が拡散することがわかる.これは明期に気根の光 合成により $\mathrm{O}_{2}$ が生成され，それが気根下部に拡散する ことを実証するものである.

この実験では切除した気根を供試しているので，光合 成に利用される $\mathrm{CO}_{2}$ の供給源は大気と気根の呼吸の及 であるが，実際には泥土中の根の呼吸作用によって生成 される $\mathrm{CO}_{2}$ が気根に拡散することが考えられる. そこ で次に Avicennia marina の直立気根について, 気根下 部から $\mathrm{CO}_{2}$ の供給がある場合とない場合の $\mathrm{O}_{2}$ 拡散量を 比較した. その結果を Fig. 5 に示す. 測定開始から 2 時間 40 分後までの暗条件下では, 気根下部容器内を 8

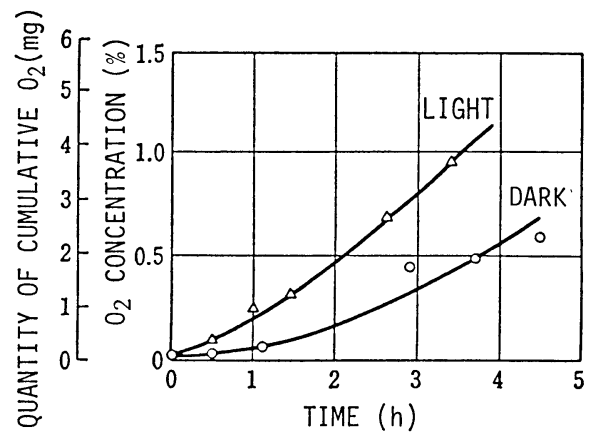

Fig. 4 Oxygen diffusion by the pneumatophore of Avicennia marina under the conditions of dark or light.

The values on the ordinate indicate the concentration and quantity of $\mathrm{O}_{2}$ in the lower receptacle shown in Fig. 2.
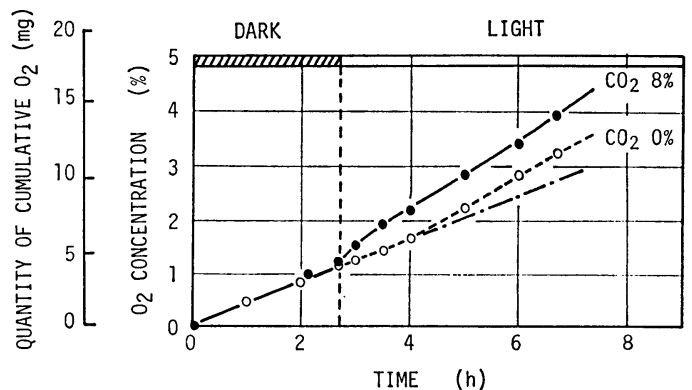

Fig. 5 Oxygen diffusion by the pneumatophore of Avicennia marina under different $\mathrm{CO}_{2}$ concentrations.

The values on the ordinate indicate the concentration and quantity of $\mathrm{O}_{2}$ in the lower receptacle shown in Fig. 2. The receptacle contained $100 \% \mathrm{~N}_{2}\left(\mathrm{CO}_{2} 0 \%\right)$, or $8 \% \mathrm{CO}_{2}$ and $92 \% \mathrm{~N}_{2}$ at the beginning of the experiment.

$\% \mathrm{CO}_{2}, 92 \% \mathrm{~N}_{2}$ で充たした区と，100\% $\mathrm{N}_{2}$ で充たし た対照区では, 気根から下部容器内に払散する $\mathrm{O}_{2}$ 量は 等しかった. その後光を照射すると両区とも $\mathrm{O}_{2}$ 拡散量 は増加し始めたが, $\mathrm{CO}_{2}$ 処理区の増加速度は対照区に比 べて約 $25 \%$ 大きくなった. Fig. 6 は Sonneratia alba の直立気根を用いて，同様の実験を明条件下のみで行っ た結果である. 処理開始 1 時間後から, $\mathrm{CO}_{2}$ 処理区の $\mathrm{O}_{2}$ 拡散量が対照区より多くなった. これらのことから, 明期には根から拡散した $\mathrm{CO}_{2}$ が気根の光合成に利用さ れ, 光合成速度が高くなり, $\mathrm{O}_{2}$ 発生速度が増加するこ とが明らかとなった。 


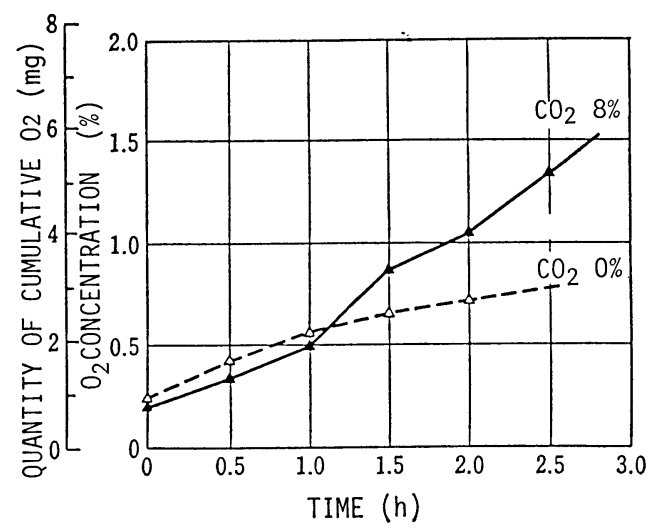

Fig. 6 Oxygen diffusion by the pneumatophore of Sonneratia alba under different $\mathrm{CO}_{2}$ concentrations.

The values on the ordinate indicate the concentration and quantity of $\mathrm{O}_{2}$ in the lower receptacle shown in Fig. 2. The receptacle contained $100 \% \mathrm{~N}_{2}\left(\mathrm{CO}_{2} 0 \%\right)$, or $8 \% \mathrm{CO}_{2}$ and $92 \% \mathrm{~N}_{2}$ at the beginning of the experiment.

\section{考察}

以上の結果から, Avicennia 属および Sonneratia 属 の直立気根のように葉緑素をもつ気根では, 従来からい われている気根表面の皮目括よび気根中の通気組織を通 したガス交換に加えて，日中には光合成反応を行い，そ れにより生成した $\mathrm{O}_{2}$ が泥土中の根に拡散して呼吸に利 用されることが明らかになった。

気根が陰葉的な光合成特性をもっていることは, 気根
が林床にあることに関係していると考えられる．すなわ ち日射量が比較的少ない林床では，低い光強度で高い光 合成活性を維持することが重要となるからである，さら に気根はほぼ鉛直に立っているので，太陽高度の高いと きに直達日射の受光量が著しく小さくなることも，陰葉 的な特性と関連しているかもしれない。

光合成に使われる $\mathrm{CO}_{2}$ として, 大気中から拡散して くるもの, 気根自身の呼吸によるものおよび根から気根 へ拡散してくるものが考兄られる. 根から気根に拡散す る $\mathrm{CO}_{2}$ の多くは根の呼吸によるものであろう。このよ うに気根で光合成により発生した $\mathrm{O}_{2}$ は，根で乎吸に利 用され，その呼吸で発生した $\mathrm{CO}_{2}$ が気根に拡散して再 び光合成の材料として使われる. 根と気根の間には, こ のようなガスの循環系が成り立っており，この機能が塩 分濃度が高く, 浸透圧が高い土䁃中から水分を吸収する ための重要な役割を担っているものと考えられる.

本研究では気根のガス交換機能を明らかにするため, 切除した気根を用いて実験を行ったが，このような気根 の機能を実証するためには，さらに生育現場において気 根のガス交換の測定を行う必要がある.

\section{文献}

1) Goebel, K. 1886. The ecology of the Aberdeen creek mangrove swamp. J. Ecol. 51: 639-703.

2) Karsten, G. 1893. Uber die Mangrovevegteation im Malayischen Archipelago. Biol. Bot. 5: 56-64.

3) Scholander, P.F., L. Van Dan and S.I. Scholander. 1955. Gas exchange in the roots of mangroves. Am. J. Bot. 42: 92-98. 